\title{
Struktur komunitas ikan karang di perairan Pulau Maitara, Kota Tidore Kepulauan. Provinsi Maluku Utara
}

\author{
(Coral fishes community structure in Maitara Island Sea, \\ Island's of Tidore. North Maluku)
}

\author{
Nebuchadnezzar Akbar ${ }^{1}$, Firdaut Ismail*, Rustam E Paembonan* \\ ${ }^{1 *}$ Program Studi Ilmu Kelautan, FPIK. Univerisitas Khairun. Ternate \\ E-mail : nezzarnebuchad@yahoo.co.id
}

\begin{abstract}
ABSTRAK
Kawasan pesisir Pulau Maitara memiliki potensi mangrove, lamun dan terumbu karang. Ekosistem terumbu karang menyediakan tempat hidup untuk berbagai jenis organisme laut. Ikan karang merupakan organisme laut yang mendiami karang untuk dijadikan sebagai tempat tinggal. Perairan pulau Maitara kaya akan keanekaragaman karang tetapi data dan informasi untuk ikan karang masih sangat sedikit. Tujuan penelitian untuk memperoleh data struktur komunitas ikan karang. Penelitian dilakukan pada April 2018. Metode pengambilan data ikan karang menggunakan metode underwater visual census (UVC).Pengambilan data kualitas air dilakukan pada setiap stasiun pengamatan. Analisis data ikan karang meliputi kelimpahan, keanekaragaman jenis, dominansi dan keseragaman jenis. Hasil penelitian menunjukan parameter lingkungan perairan mendukung kehidupan terumbu karang dan biota perairan. Identifikasi ikan karang ditemukan 8 famili, 19 genus dan 54 spesies dengan total individu 460 ekor. Ikan karang ditemukan tiga kelompok yakni ikan indikator, ikan target dan ikan mayor. spesies dari genus Chaetodon banyak ditemukan dibandingkan dengan yang lain. Kelimpahan ikan karang berdasarkan stasiun pengamatan diperoleh stasiun I yakni $0,51 \mathrm{ind} / \mathrm{m}^{2}$, stasiun II $0,39 \mathrm{ind} / \mathrm{m}^{2}$ III yaitu $0,41 \mathrm{ind} / \mathrm{m}^{2}$. Kelimpahan ikan indikator adalah 0,50 individu $/ \mathrm{m}^{2}$, ikan target $0,77 \mathrm{ind} / \mathrm{m}^{2}$ dan ikan mayor $0,05 \mathrm{ind} / \mathrm{m}^{2}$. Indeks keanakeragaman ikan ditemukan secara keseluruhan masuk dalam kategori tinggi, nilai indek dominansi yang ditemukan memperlihatkan dominansi yang rendah dan indeks keseragaman jenis menunjukan bahwa komunitas dalam keadaan stabil.
\end{abstract}

Kata kunci : Dominansi, ikan karang, kelimpahan, keanekaragaman, keseragaman, pulau Maitara dan underwater visual census.

\begin{abstract}
Coastal Maitara Island finded potential mangroves, seagrass and coral reef. The coral reef ecosystem providing habitats of marine organism. Coral fish is marine organism that inhabits coral reef to serve as residence. The Maitara Island sea has high biodiversity, but the data and information of coral reef fish minimal reported. The research perform in April 2018. Coral fish research method was used is an underwater visual census (UVC). Water qualty data was taken in each stations. Coral reef fish analysis data divided abudance $(X)$, diversity index $\left(H^{\prime}\right)$, dominance index $(C)$ and equitability index $(E)$. The result showed that qualty water index supported the coral reefs and marine organism. The visual census results collected founded 8 families, 19 genus and 54 specieses with 460 individuals. Coral fish divided three group that is idicator fish, target fish and major. The genus Chaetodon founded more than others. Coral fish density of station I was $0,51 \mathrm{ind} / \mathrm{m}^{2}$, station II was $0,39 \mathrm{ind} / \mathrm{m}^{2}$ and station III was $0,41 \mathrm{ind} / \mathrm{m}^{2}$. Indicator fish density was $0,50 \mathrm{ind} / \mathrm{m}^{2}$, target fish was $0,77 \mathrm{ind} / \mathrm{m}^{2}$ and major fish was 0,05 ind $/ \mathrm{m}^{2}$. The diversity index ( $\left.H^{\prime}\right)$ founded into high category, dominance index $(C)$ show that low dominance and equitability index $(E)$ showed that stability community.
\end{abstract}

Keyword : Coral fish, density, diversity, dominance, equitability, Maitara island and underwater visual census 


\section{Pendahuluan}

Indonesia merupakan negara kepulauan yang memiliki \pm 17.000 pulau dengan garis pantai $81.000 \mathrm{~km}$, negara ini memiliki potensi sumberdaya pesisir sangat besar dan beranekaragam. Potensi sumberdaya terdiri dari sumberdaya alam dapat pulih (renewable resources), dan sumberdaya tidak dapat pulih (unrenewable resources), dan jasa-jasa lingkungan. Dengan demikian kawasan pesisir dan laut memiliki potensi untuk digunakan dan dikembangkan untuk kepentingan bersama.

Pulau Maitara secara administrasi masuk dalam Kota Tidore Kepulauan, Provinsi Maluku Utara. Kawasan pesisir Pulau Maitara memiliki potensi hutan mangrove, lamun dan terumbu karang (Akbar et al, 2017b). Ekosistem terumbu karang merupakan salah satu penyusun ekosistem di pulau ini. Keberadaan ekosistem ini memberikan manfaat kepada masyarakat secara ekologi, ekonomi dan sosial. Manfaat lain yang diperoleh yaitu berlimpahnya ikan didaerah sekitar terumbu karang. Hal ini dikarenakan, ikan menjadikan terumbu karang sebagai habitat. Terumbu karang bisa dijadikan ikan dan biota laut lainnya sebagai daerah pencari makanan, persinggahan maupun asuhan. Terumbu karang merupakan penyuplai nutrien terpenting dalam perairan (Nasir et al, 2017). Selain itu terumbu karang juga berfungsi sebagai pelindung pantai dari degradasi dan abrasi (Nasir et al., 2017). Berbagai macam larva ikan bisa tumbuh dan berkembang didaerah terumbu karang.

Ikan karang merupakan salah satu organisme laut yang hidup dan berkembang didaerah terumbu karang. Komunitas ikan karang merupakan bagian yang penting dalam menjaga keseimbangan dengan berbagai komponen penyusun ekosistem terumbu karang (Nasir et al, 2017). Menurut Allen (2005) menyatakan bahwa dari perkiraan 12.000 spesies ikan laut dunia, kurang lebih 7.000 spesies $(58,3 \%)$ merupakan ikan yang hidup didaerah terumbu karang, tetapi tidak semua ikan tersebut hidup dalam satu habitat yang sama. Mereka tersebar di beberapa bagian menurut kesukaan mereka tehadap habitat (Nybakken, 1993).

Penelitian ikan karang di Indonesia telah banyak dilaporkan. Beberapa penelitian ikan karang dilaporkan Mayunar (1996) tentang ikan karang ekonomi penting, Dhahiyat et al (2003), Satria dan Mujiyanto (2011) di perairan teluk Saleh, Nusa Tenggara Barat, Ratnawati et al (2011) di kepulauan Kayoa, Maluku Utara, Yunaldi et al (2011) di perairan Kabupaten Buleleng, Bali, Bakhtiar et al (2012) di perairan pulau Tikus kota Bengkulu, LIPI (2012) di perairan Ternate, Tidore dan sekitarnya, Andrim et al (2012) di perairan Kendari, Najamuddin et al (2012) di perairan pulau Makian, Cinnawara et al (2015) di perairan pulau Luwu. Laporan penelitian diatas menunjukan pentingnya kajian ikan karang di suatu perairan, dikarenakan dijadikan sebagai indikator kondisi habitat. Tutupan karang di perairan pulau Maitara masuk kategori sedang 25-50\% (LIPI, 2016). Informasi ini memberikan gambaran bahwa perairan pulau Maitara kaya akan keanekaragaman karang. Akan tetapi data dan informasi untuk ikan karang masih sangat sedikit,sehingga perlu dilakukan kajian tentang ikan karang untuk dijadikan sebagai sumber informasi untuk dijadikan sebagai dasar dalam pengelolaan. Penelitian ini bertujuan untuk mengungkap struktur komunitas ikan karang di perairan pulau Maitara, Kota Tidore Kepulauan, Provinsi Maluku Utara. 


\section{Metode Penelitian}

\subsection{Waktu dan tempat penelitian}

Penelitian dilaksanakan pada bulan April 2018 pada tiga lokasi ; Desa Pasimayao (stasiun I), Sari Mauli (lokasi wisata) (stasiun II) dan Ake Bai (stasiun III) (Gambar 1).

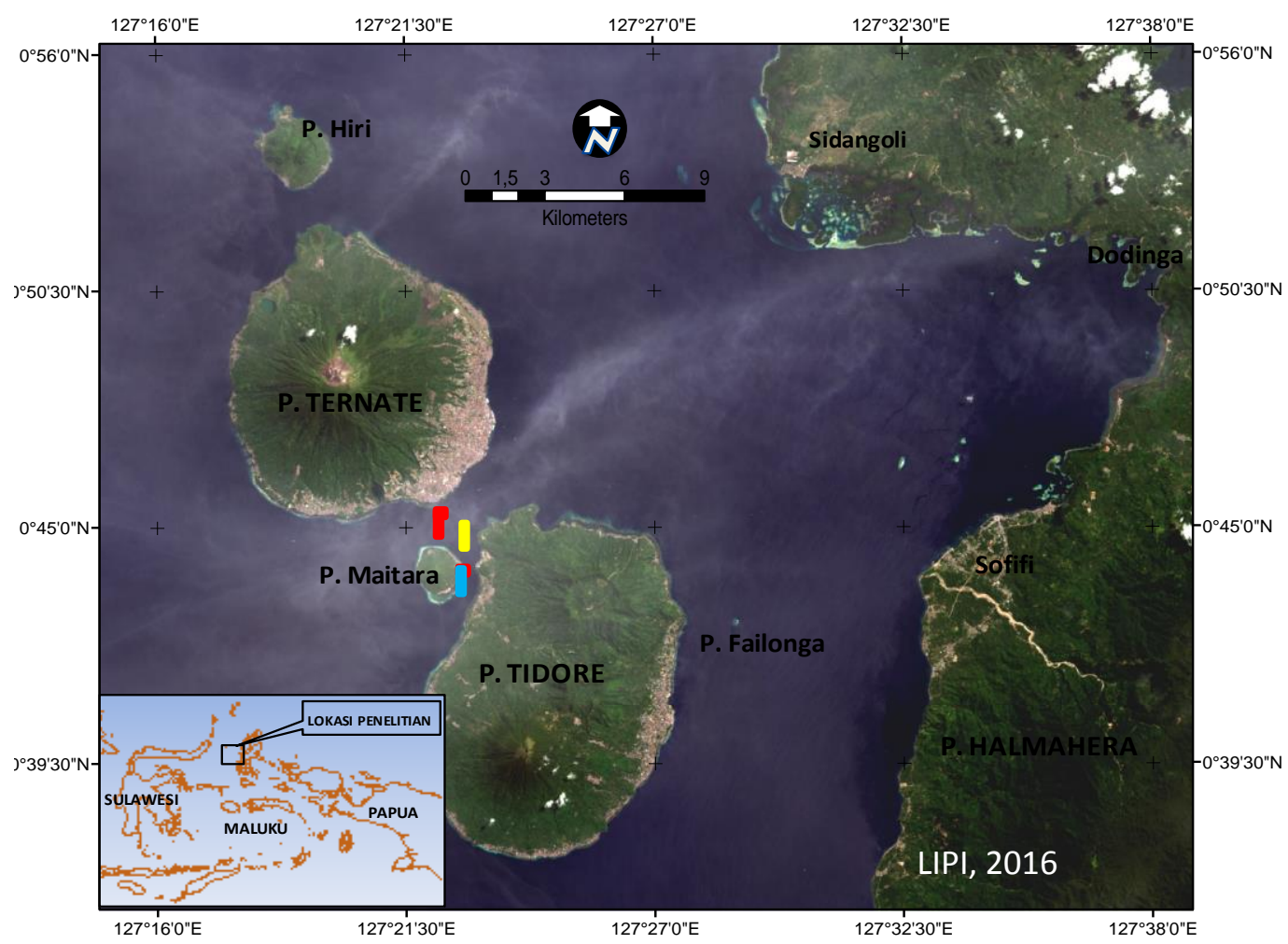

Gambar 1. Peta Lokasi $($ merah = stasiun I, kuning = stasiun II dan biru = stasiun III $)$

Peralatan penelitian digunakan untuk mendukung kegiatan survey lapangan ;

Tabel 1. Peralatan survey dan kegunaan

\begin{tabular}{cll}
\hline No & \multicolumn{1}{c}{ Peralatan Survey } & \multicolumn{1}{c}{ Kegunaan } \\
\hline 1 & GPS & Posisi Lokasi \\
2 & Alat Selam Dasar & Pengamatan \\
3 & Scuba Diving & Pengamatan \\
4 & Underwater Camera & Dokumentasi \\
5 & Papan Sabak & Media Penyimpan Data \\
6 & Pensil & Alat Tulis \\
7 & Buku Identifikasi & Pedoman Identifikasi \\
\hline
\end{tabular}

\subsection{Pengambilan data ikan karang}

Metode pengambilan data ikan karang menggunakan metode Underwater Visual Census (English et al, 1994). Transek sepanjang 50 meter dibuat sejajar dengan tubir atau garis pantai, dengan jarak pengamatan memakai garis khayal sejauh lima meter kiri dan kanan dari garis transek. Pada masing-masing lokasi ditempatkan tiga transek (tiga pengulangan) dengan jarak tiap transek $5 \mathrm{~m}$. Garis transek ditempatkan pada kedalaman 10 meter. Identifikasi ikan jenis-jenis tertentu melalui foto atau video 
dilakukan antara lain berdasarkan Allen et al (1999), Peristiwady (2006) dan Setiawan (2010).

Pengambilan data kualitas air dilakukan pada setiap stasiun pengamatan. Parameter-parameter yang diukur secara langsung (in situ) meliputi: suhu, salinitas, $\mathrm{pH}$, Kecerahan, oksigen terlarut. Kemudian analisis kualitas air dilakukan dengan melihat pola sebaran dari parameter-parameter pada lapisan permukaan sekitar perairan. Data kualitas air yang diperoleh dianalisis secara deskriptif dan dibandingkan dengan Keputusan Menteri Negara Lingkungan Hidup Nomor 51 Tahun 2004 tentang Baku Mutu Air Laut untuk Biota Laut

\subsection{Analisis data}

Data lapangan yang diperoleh kemudian dianalisis untuk melihat kelimpahan (X) (Odum,1993), keanekaragaman jenis (H') (Krebs, 1989), dominansi (C) (Odum,1993) dan keseragaman jenis (E) (Odum,1993).

\section{Hasil dan Pembahasan}

\subsubsection{Parameter lingkungan}

Keseluruhan hasil pengukuruan parameter lingkungan menunjukan bahwa kualitas perairan mendukung kehidupan terumbu karang dan biota perairan lainnya (Tabel 2). Menurut Nybakken (1992) dan Veron (2000), terumbu karang hidup pada salinitas $32-35 \%$ dan suhu air antara $23-25^{\circ} \mathrm{C}$ dengan jenis substrat yang keras dan bersih sebagai tempat melekatya larva planula, sehingga memungkinkan pembentukan koloni baru. Menurut Kaswaji dalam Aryani (2011), kondisi perairan ekosistem terumbu karang dengan $\mathrm{pH}$ 7,5-8,5 mempunyai produktivitas tinggi. Kondisi fisik perairan terumbu karang tersebut mempengaruhi kelestarian dari ekosistem terumbu karang. Distribusi dan pertumbuhan ekosisitem terumbu karang tergantung dari beberapa parameter fisika dan kimia laut yaitu suhu, salinitas dan kecerahan (Dahuri, 2003)

Tabel 2. Lokasi pengamatan suhu, salinitas, kecerahan, do dan koordinat

\begin{tabular}{|c|c|c|c|c|c|c|c|}
\hline No & Lokasi Pengamatan & Suhu & Salinitas & Kecerahan & DO & $\mathrm{pH}$ & Koordinat \\
\hline 1 & Desa Pasimayou & 26 & 33 & 23 & 6.2 & 8,13 & $\begin{array}{l}\text { N } 00^{\circ} 43^{\prime} .64^{\prime \prime} \\
\text { E } 127^{\circ} 22^{\prime} .60^{\prime \prime}\end{array}$ \\
\hline 2 & $\begin{array}{l}\text { Sari Mauli } \\
\text { (lokasi wisata) }\end{array}$ & 26 & 33 & 20 & 6.3 & 8,3 & $\begin{array}{l}\text { N } 00^{\circ} 44^{\prime} .27^{\prime \prime} \\
\text { E } 127^{\circ} 22^{\prime} .61^{\prime \prime}\end{array}$ \\
\hline 3 & Desa Akebai & 26 & 32 & 22 & 6.2 & 8,18 & $\begin{array}{l}\text { N } 00^{\circ} 44^{\prime} .47^{\prime \prime} \\
\text { E } 127^{\circ} 21^{\prime} .99^{\prime \prime}\end{array}$ \\
\hline
\end{tabular}

Cahaya merupakan salah satu faktor yang paling penting yang membatasi terumbu karang, cahaya yang cukup harus tersedia agar fotosintesis oleh zooxanthellae simbiotik dalam jaringan karang dapat terlaksana, titik kompensasi untuk karang merupakan kedalaman dengan intensitas cahaya berkurang sampai 15- $20 \%$ dari intensitas di permukaan.Kualitas air yang diukur masih di bawah ambang baku mutu air laut untuk kehidupan biota laut, berdasarkan perbandingan nyata dengan baku mutu perairan sesuai peruntukannya yang berlaku di Indonesia yakni mengacu pada Kepmen LH No. 51 Tahun 2004 tentang Baku Mutu Air Laut untuk Biota Laut. 


\subsubsection{Komposisi dan kelimpahan ikan karang}

Hasil pengamatan ikan karang ditemukan 8 famili, 19 genus dan 54 spesies dengan total individu 460 ekor (Tabel 3).

Tabel 3.Kategori, famili, genus, spesies dan jumlah ikan karang

\begin{tabular}{|c|c|c|c|c|c|}
\hline No & Kategori & Famili & Genus & Spesies & Jumlah \\
\hline 1 & \multirow{18}{*}{$\begin{array}{c}\text { Ikan } \\
\text { Indikator }\end{array}$} & \multirow{18}{*}{ Chaetodontidae } & \multirow{13}{*}{ Chaetodon } & Chaetodon auriga & 15 \\
\hline 2 & & & & $\begin{array}{l}\text { Chaetodon } \\
\text { baronessa }\end{array}$ & 8 \\
\hline 3 & & & & $\begin{array}{l}\text { Chaetodon } \\
\text { bennetti } \\
\text { Chaetodon }\end{array}$ & 10 \\
\hline 4 & & & & citrinellus & 19 \\
\hline 5 & & & & Chaetodon kleinii & 32 \\
\hline 6 & & & & $\begin{array}{l}\text { Chaetodon } \\
\text { lunulatus } \\
\text { Chaetodon }\end{array}$ & 8 \\
\hline 7 & & & & $\begin{array}{l}\text { melannotus } \\
\text { Chaetodon }\end{array}$ & 6 \\
\hline 8 & & & & $\begin{array}{l}\text { ocelicaudus } \\
\text { Chaetodon }\end{array}$ & 6 \\
\hline 9 & & & & $\begin{array}{l}\text { rafflesii } \\
\text { Chaetodon }\end{array}$ & 4 \\
\hline 10 & & & & $\begin{array}{l}\text { triangulum } \\
\text { Chaetodon }\end{array}$ & 7 \\
\hline 11 & & & & $\begin{array}{l}\text { trifascialis } \\
\text { Chaetodon }\end{array}$ & 13 \\
\hline 12 & & & & $\begin{array}{l}\text { trifasciatus } \\
\text { Chaetodon }\end{array}$ & 8 \\
\hline 13 & & & & vagabundus & 12 \\
\hline 14 & & & Coradion & $\begin{array}{l}\text { Coradion } \\
\text { melanopus }\end{array}$ & 4 \\
\hline 15 & & & \multirow{3}{*}{ Heniochus } & $\begin{array}{l}\text { Heniochus } \\
\text { chrysostomus }\end{array}$ & 7 \\
\hline 16 & & & & $\begin{array}{l}\text { Heniochus } \\
\text { singularis }\end{array}$ & 4 \\
\hline 17 & & & & Heniochus varius & 8 \\
\hline 18 & & & Forcipiger & $\begin{array}{l}\text { Forcipiger } \\
\text { flavissimus }\end{array}$ & 5 \\
\hline Total & & 1 & 4 & 18 & 176 \\
\hline 20 & $\begin{array}{c}\text { Ikan } \\
\text { Target }\end{array}$ & Acanthuridae & Acanthurus & $\begin{array}{l}\text { Acanthurus } \\
\text { auranticavus } \\
\text { Acanthurus } \\
\text { blochii } \\
\text { Acanthurus }\end{array}$ & 5 \\
\hline
\end{tabular}


Acanthurus mata

Acanthurus

nigricans

Acanthurus

nigrofuscus

Acanthurus

olivaceus

Acanthurus

pyroferus

Acanthurus

thompsonii 5

Ctenochaetus

binotatus

Ctenochaetus

Ctenochaetus

striatus

35

Ctenochaetus

tominiensis

Naso hexacanthus 6

Naso lopezi

Naso vlamingi

Zebrasoma

\begin{tabular}{ll} 
Naso vlamingi & 6 \\
\hline Zebrasoma
\end{tabular}

scopas

Zebrasoma

veliferum

6

Plectorhinchus

\begin{tabular}{cc}
\hline Haemulidae & Plectorhinchus \\
\hline Lethrinidae & Monotaxis
\end{tabular}

9

Monotaxis granducolis 14

Lutjanus

carponotatus

6

Lutjanus

Lutjanidae

Lutjanus

decussatus

4

Lutjanus

fulviflammus

7

Anyperodon

leucogrammicus

5

Cephalopholis

argus

6

Cephalopholis

Serranidae

Cephalopholis

cyanostigma

4

Cephalopolis

micropion

Cephalopholis

urodeta

3

Epinephelus

Epinephelus

fasciatus

6

Epinephelus

5


merra

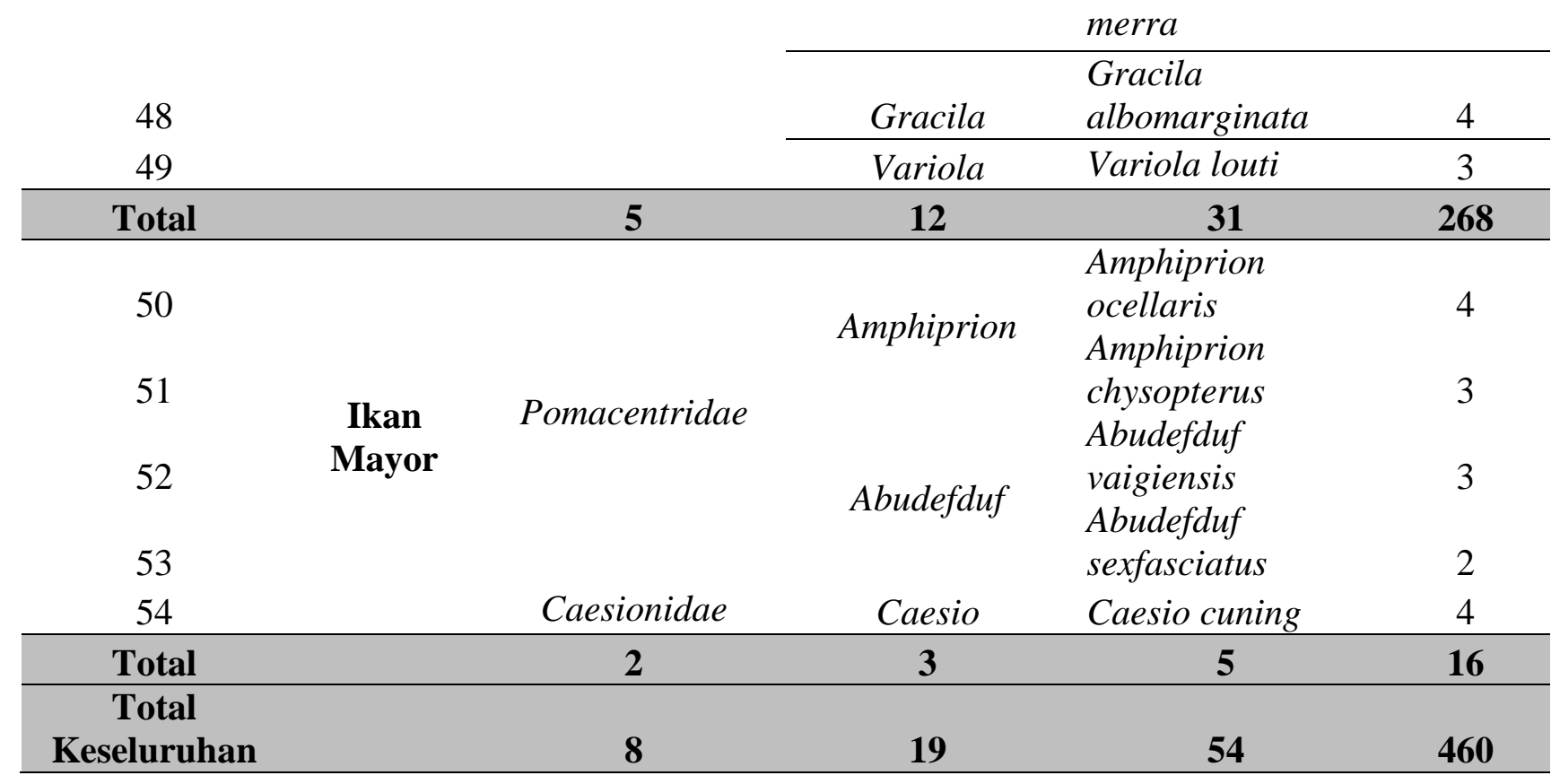

Pengamatan yang dilakukan menunjukan bahwa jumlah famili dan spesies ikan karang sangat beragam di perairan pulau Maitara, hal ini kemungkinan dikarenakan karena ketiga bagian lokasi pulau masih memiliki karang dan kondisi perairan cukup baik. Selain itu faktor kondisi substrat dan keberagaman karang yang cukup tinggi, berpengaruh terhadap kelimpahan dan keanekaragaman ikan karang. Nasir et al (2017) mengatakan bahwa kondisi substrat dan variasi karang suatu perairan, memberikan pengaruh terhadap kehadiran, jumlah dan keberagaman ikan karang. Laporan LIPI (2015) menyebutkan total luas terumbu karang di pulau Maitara adalah 97,38 ha, sedangkan LIPI (2016) mengatakan kondisi terumbu karang pulau Maitara masuk dalam kategori sedang. Hal ini tentunya memberikan pengaruh terhadap kehadiran biota perairan yang berasosiasi dengan terumbu karang. Najamuddin et al (2012) menemukan hasil yang berbeda, dimana ditemukan 47 genus dan 21 famili dengan total individu sebanyak 2.404 ekor. Perbedaan ini diakibatkan karena kondisi habitat dan topografie serta aktivitas di daerah pantai yang berbeda. Dampak aktivitas masyarakat tersebut memberikan pengaruh terhadap terjadinya perubahan kualitas lingkungan perairan yang kemudian secara langsung maupun tidak langsung mempengaruhi pertumbuhan dan kelangsungan hidup karang dan ikan karang (Najamuddin et al, 2012).

Ikan karang yang diperoleh dapat di kelompokan ke dalam tiga kelompok yakni ikan indikator, ikan target dan ikan mayor. Kelompok ikan indikator yaitu dari family Chaetodontidae, kelompok ikan target yaitu dari famili Acanthuridae, Haemulidae, Lethrinidae, Serranidae dan Lutjanidae dan kelompok ikan mayor ditemukan famili Pomacentridae dan Caesionidae. Jumlah spesies ikan indikator dari family Chaetodontidae yang ditemukan sebanyak 18 spesies, pada ikan target famili Acanthuridae sebanyak 17 spesies, Haemulidae 1 spesies, Lethrinidae 1 spesies, Serranidae 9 spesies dan Lutjanidae 3 spesies dan ikan mayor famili Amphiprion terdapat 2 spesies, Abudefduf ditemukan 2 spesies dan Caesio diperoleh 1 spesies (Tabel 3). Hasil penelitian yang sama juga diperoleh Andrim et al (2012) yang menemukan 17 spesies ikan dan ikan target Acanthuridae (8 jenis), 
Siganidae (5 jenis), Lutjanidae (4 jenis), Haemulidae (3 jenis), Mullidae (2 jenis), Scaridae (2 jenis), Caesionidae (2 jenis), Serranidae (1 jenis), Lethrinidae (1 jenis), Nemipteridae (1 jenis), dan Carangidae (1 jenis). Tiga kelompok ikan yang ditemukan, juga diperoleh Najamuddin et al (2012) di perairan pulau Makian, Setiawan et al (2013) di perairan Bunaken Taman Nasional Bunaken dan Cinnawara et al (2015) di perairan Luwu, NTB. Hal ini menunjukan bahwa peluang kehadiran tiga kelompok ikan ini sangat tinggi. Namauddin et al (2012) menyebutkan bahwa kelompok ikan mayor umumnya hidup dalam kelompok besar (schooling fish) dan banyak terdapat di daerah terumbu karang yang memiliki tipe terumbu karang bercabang, kelompok ikan target merupakan ikan konsumsi atau ikan ekonomis penting yang hidup berasosiasi kuat dengan perairan dan kelompok ikan indikator umumnya hidup soliter dan merupakan jenis-jenis ikan yang umumnya digunakan sebagai indikator.

Keseluruhan hasil pengamatan menunjukan bahwa jumlah jenis dari genus Chaetodon lebih banyak ditemukan dibandingkan dengan yang lain (Tabel 3). Ikan ini merupakan jenis ikan indikator kesehatan terumbu karang. Selain itu tingkat ekploitasi terhadap ikan ini sangatlah minim, dengan demikian populasi memiliki kesempatan untuk tumbuh dan bekembang. Satria dan Mujiyanto (2011) menemukan hal yang sama di perairan Teluk Saleh, NTB, selain itu Andrim et al (2012) mengakatan bahwa Ikan jenis tersebut tersebar luas di semua lokasi pengamatan di perairan Kendari.

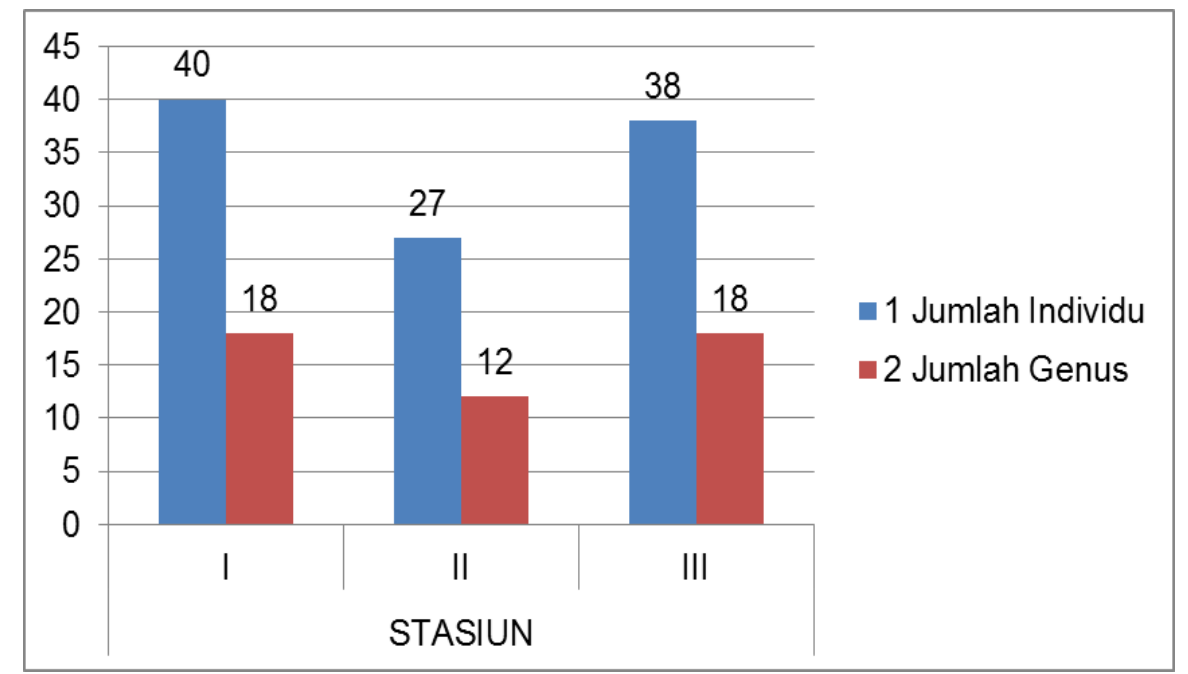

Gambar 2. Jumlah individu dan genus ikan karang di perairan pulau Maitara

Kehadiran ikan ini memberikan gambaran bahwa kondisi terumbu karang secara ekologi masih mampu dijadikan sebagai habitat. Satria dan Mujiyanto (2011) menjelaskan bahwa dengan adanya terumbu karang memberikan dampak positif untuk menarik jenis ikan indikator untuk mencari makanan dan pada ronggarongga terumbu karang. Marsaoli (1998) menyatakan bahwa terdapat respon linear positif sangat nyata antara hubungan penutupan karang hidup dan densitas ikan karang. Sedangkan Yunaldi et al (2011) mengatakan bahwa genus Chaetodon merupakan jenis ikan penetap di daerah terumbu karang, sehingga ditemukan disetiap perairan yang memiliki terumbu karang. 
Total jumlah individu dan genus ikan karang pada stasiun pengamatan I ditemukan 40 individu dan 18 genus, stasiun II terdapat 27 individu dan 12 genus, sedangkan stasiun III diperoleh 38 individu dan 18 genus (Gambar 2). Jumlah jenis ikan karang berdasarkan kategori, ditemukan pada kategori ikan indikator sebanyak 1 famili, 4 genus, 18 spesies dengan total sebanyak 176 individu, ikan target ditemukan 5 famili, 12 genus, 31 spesies dengan keseluruhan 268 individu dan ikan mayor diperoleh 2 famili, 2 genus dan 5 spesies (Tabel 3). Hasil yang ditemukan menggambarkan bahwa komposisi genus dan individu masih bervariasi dan memiliki hubungan dengan keberadaan terumbu karang. Suharsono (1996) juga menambahkan bahwa tutupan karang yang baik akan memberikan keuntungan berupa tempat tinggal, perlindungan, tempat mencari makan dan berkembang biak bagi ikan dan biota yang berasosiasi dengannya. Laporan LIPI $(2015 ; 2016)$ diperoleh hasil yang sama, dimana terdapat variasi jumlah individu dan genus pada setiap lokasi penelitian. Kehadiran ikan indikator di lokasi perairan menandakan bahwa kesehatan dan kondisi terumbu karang di perairan Maitara masih baik. Ikan ini merupakan ikan yang berasosiasi paling kuat dengan karang, sehingga bila dalam suatu ekosistem terumbu karang ikan ini tidak ditemukan maka kondisi ekosistem tergolong rusak atau dalam keadaan tidak baik (Nybakken, 1997)

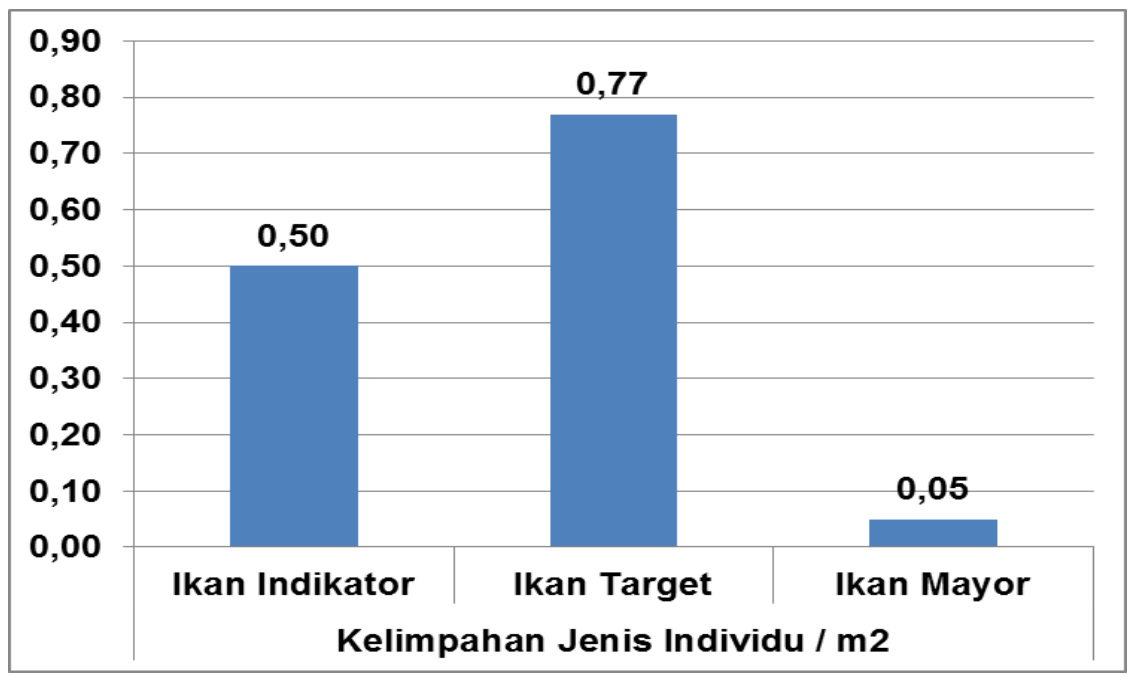

Gambar 3. Kelimpahan ikan indikator, target dan mayor di perairan Pulau Maitara

Hasil pengamatan menemukan bahwa kelimpahan ikan indikator sebanyak 0,50 individu $/ \mathrm{m}^{2}$, ikan target $0,77 \mathrm{ind} / \mathrm{m}^{2}$ dan ikan mayor $0,05 \mathrm{ind} / \mathrm{m}^{2}$ (Gambar 3). Tingginya kelimpahan ikan target disebabkan karena jumlah genus dan jenis yang banyak ditemukan pada setiap stasiun. Setiawan et al (2013) menemukan hal yang sama, dimana ikan target dengan nilai kelimpahan tertinggi di perairan Taman Nasional Bunaken. Hasil berbeda ditemukan Cinawarra et al (2015) di perairan Luwu dan Bakhtiar et al (2012) di perairan pulau Tikus, Bengkulu, dimana ikan mayor paling berlimpah. Namun demikian Kondisi ini menggambarkan masih tingginya keanekaragaman ikan karang (Bakhtiar et al, 2012). Selain itu Satria dan Mujiyanto (2011) menemukan bahwa ikan mayor mendominasi perairan teluk Saleh, NTB. Perbedaan hasil yang dipereoleh diakibatkan perbedaan relung habibat dan kondisi perairan setiap lokasi pengamatan. Kehadiran ikan mayor, ikan target dan ikan indikator di perairan pulau Maitara masuk dalam kategori normal normal, 
terlebih lagi masih tingginya kehadiran ikan indikator, yang menandakan kondisi terumbu karang masih baik.

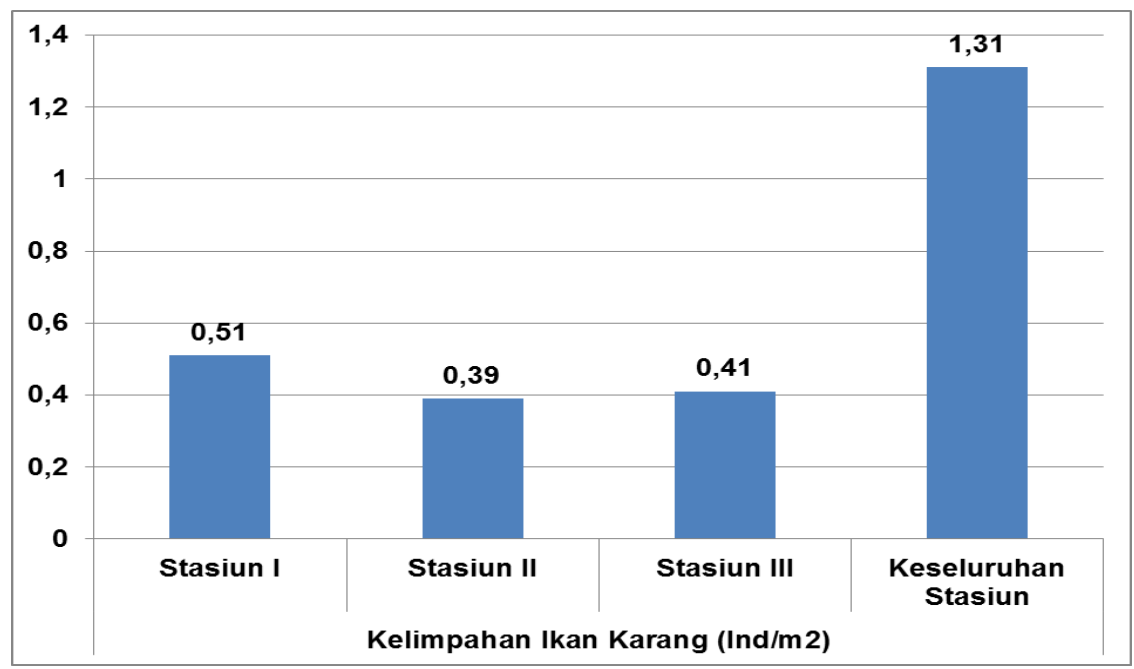

Gambar 4. Kelimpahan ikan karang per stasiun dan keseluruhan stasiun

Kelimpahan ikan karang berdasarkan stasiun pengamatan diperoleh stasiun I yakni $0,51 \mathrm{ind} / \mathrm{m}^{2}$, stasiun II $0,39 \mathrm{ind} / \mathrm{m}^{2}$ III yaitu $0,41 \mathrm{ind} / \mathrm{m}^{2}$. Sedangkan secara keseluruhan kelimpahan ikan karang di perairan pulau Maitara yakni 1,31 ind $/ \mathrm{m}^{2}$ (Gambar 4). Nilai kelimpahan dapat menggambarkan keadaan serta jenis ikan karang yang mendominasi di suatu tempat. Kelimpahan ikan tertinggi ditemukan pada stasiun I disebabkan karena kondisi karang yang cukup baik. Selain itu pada stasiun I, juga ditemukan ekosistem mangrove dan lamun, dengan demikian menjadi habitat ikan untuk berkembang. Hasil penelitian Satria dan Mujiyanto (2011) di perairan teluk Saleh, NTB menemukan hasil yang sama yakni ditemukan stasiun yang memiliki kelimpahan paling tinggi diantara stasiun lainnya.

\subsubsection{Keanakaragaman, dominansi dan keseragaman ikan karang}

Hasil analisis indeks keanekaragaman ikan setiap stasiun, menemukan nilai yang bervariasi (Gambar 05). Stasiun I memperoleh nilai keanekaragaman ikan 3,12, stasiun II ditemukan nilai 2,83 dan stasiun III dengan nilai sebesar 3,27. Distribusi nilai keanekaragaman ikan pada setiap stasiun menunjukan bahwa stasiun III memperoleh nilai paling tinggi dibandingkan dengan stasiun lainnya. Sedangkan nilai keanakeragaman keseluruhan stasiun di perairan pulau Maitara sebesar 3,44 (Gambar 5). Berdasarkan kategori indeks keanakeragaman ikan, maka nilai yang ditemukan secara keseluruhan masuk dalam kategori tinggi $\left(\mathrm{H}^{\prime} \geq 3\right)$. Hal ini menunjukkan bahwa perairan Pulau Maitara masih memiliki lingkungan perairan yang baik, selain itu eksploitasi terhadap ikan karang masih sangat rendah. Kondisi terumbu karang turut memberikan pengaruh terhadap kehadiran dan keanekaragaman jenis ikan karang. Nybakken (1993) bahwa nilai keanekaragaman tinggi menandakan lingkungan yang nyaman dan stabil sedangkan nilai keanekaragaman rendah menandakan lingkungan yang menyesakkan dan berubahubah. Hasil yang serupa juga ditemukan Ratnawati et al (2011) di perairan pulau Kayoa, Bakhtiar et al (2012) di perairan pulau Tikus, Bengkulu, Najamuddin et al (2012) di perairan pulau Makian, Provinsi Maluku Utara, Andrim et al (2012) di perairan Kendari, Setiawan et al (2013) di perairan Taman Nasional Bunaken dan 
Nasir et al (2017) di perairan pulau Batee, Aceh. Kehadiran ikan karang yang bervariasi dengan jumlah yang banyak pada setiap lokasi pengamatan memberikan pengaruh tingkat keanekaragaman di perairan Maitara.

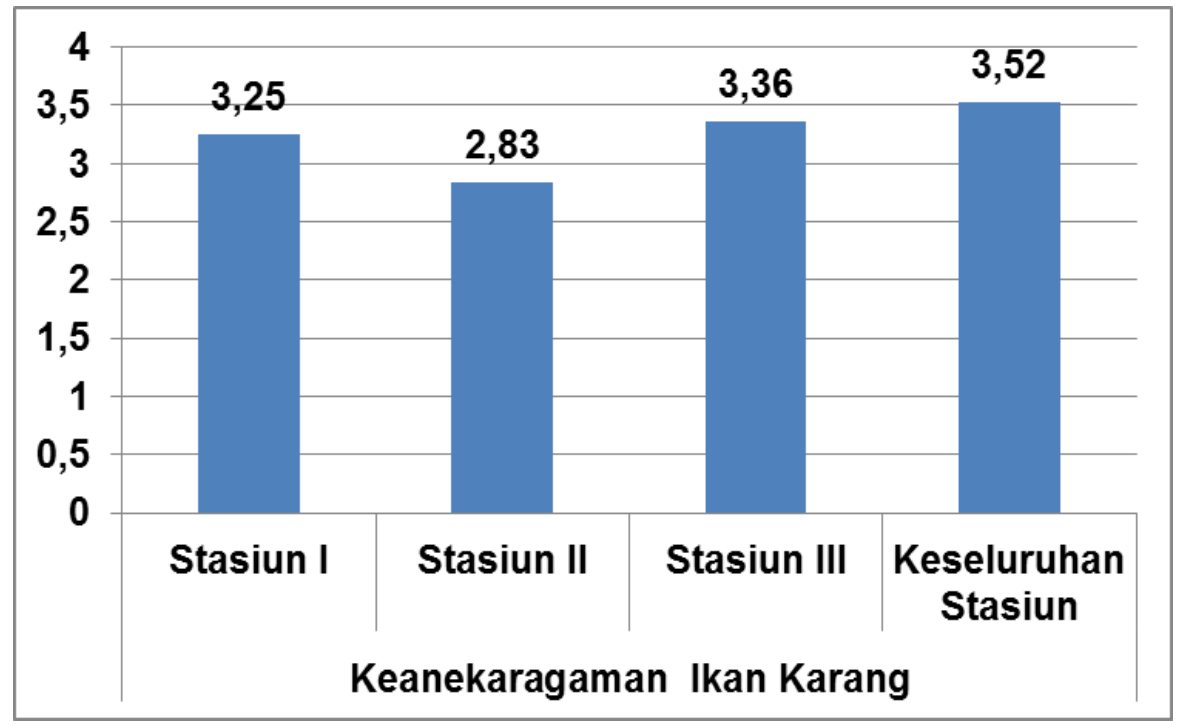

Gambar 5. Keanekaragaman ikan karang per stasiun pengamatan

Distribusi terumbu karang secara merata di bagian Utara, tengah dan selatan, dengan demikian memungkinkan untuk dijadikan sebagai habitat ikan karang Kondisi kesehatan terumbu karang turut memberikan pengaruh terhadap terhadap komposisi jenis ikan karang, selain itu faktor ekologi di perairan memberikan peluang berbagai jenis ikan yang berasosiasi. Kondisi arus juga memberikan pengaruh terhadap lingkungan sekitar. Kondisi arus perairan Pulau Maitara yang stabil, mendistribusikan bahan makanan bagi komunitas ikan karang. Indeks dominansi ikan karang pada ketiga stasiun menggambarkan adanya perbedaan dengan kisaran nilai 0,05-0,09 (Gambar 6). Secara keseluruhan indeks dominansi ikan karang diperairan pulau Maitara adalah 0,06. Hal ini menjelaskan bahwa tidak terdapat spesies ikan karang yang mendominan. Selain itu berdasarkan kategori, maka nilai yang ditemukan memperlihatkan bahwa terdapat dominansi yang rendah. Odum (1993) jika nilai indeks dominansi dibawah 0,5 menunjukkan dominansi rendah. Tingginya variasi ikan karang yang ditemukan, mempengaruhi komposisi dan dominansi suatu komunitas.

Kelimpahan ikan yang banyak tidak didominansi beberapa spesies, sehingga sulit untuk diamati karena ikan tersebar secara merata. Andrim et al (2012) mengatakan dominansi rendah menunjukkan sebaran populasi merata dan tidak adanya pemusatan individu pada jenis tertentu. Hasil penelitian serupa juga dilaporkan Yunaldi et al (2011) di terumbu buatan di perairan di Kabupaten Buleleng, Bali, Andrim et al (2012) di perairan Kendari dan Nasir et al (2017) di perairan Batee Kecamatan Peukan Bada, Kabupaten Aceh Besar. Sebaran ikan yang merata diseluruh lokasi pengamatan memberikan gambaran bahwa kondisi perairan dan habitat yang baik. Distribusi terumbu karang, lamun dan mangrove di wilayah pesisir pulau Maitara, memberikan kontribusi dalam penyediaan rantai makanan. Komposisi ikan indikator dan target yang bervariasi mempengaruhi dominansi spesies setiap komunitas. Penyebaran ikan karang yang luas di wilayah terumbu karang, dikarenakan wilayah ini menyediakan sumber makanan, tempat 
berkembang dan daerah persinggahan. Teritorial ikan karang yang luas disuatu wilayah terumbu, memberikan kesempatan ikan untuk menyebar lebih luas. Secara ekologi dominansi yang rendah memperlihatkan kondisi ekologis perairan di lokasi tersebut relatif masih stabil atau lebih alami dibanding lokasi lainnya.

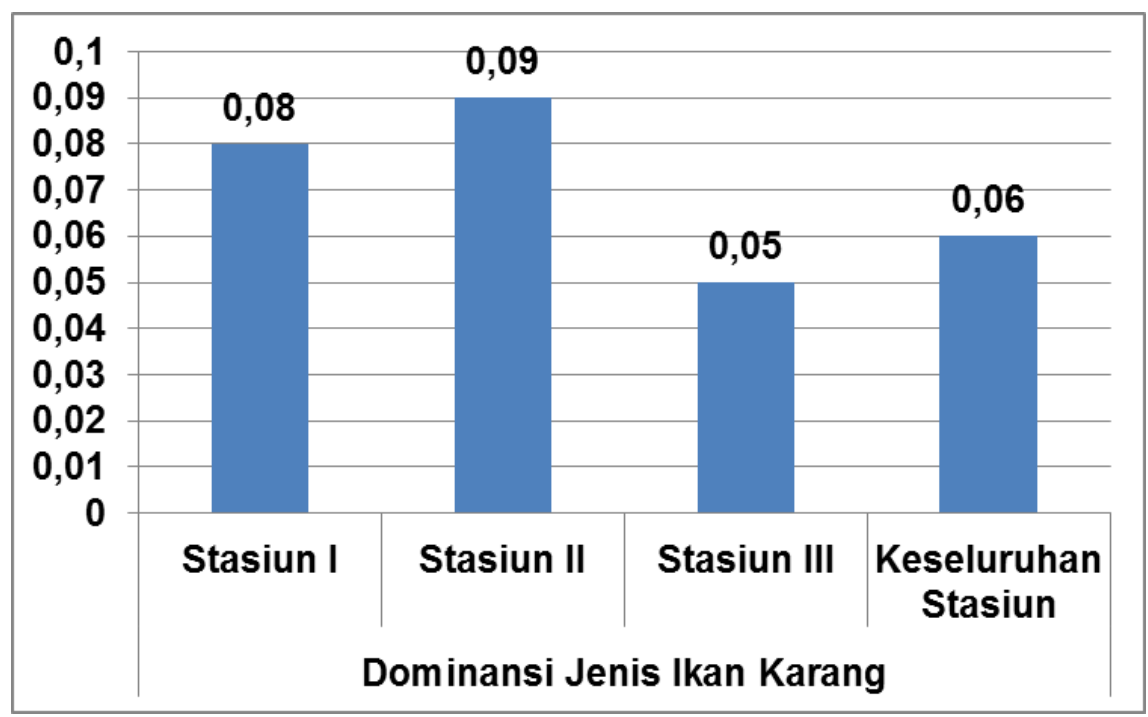

Gambar 6. Dominansi ikan karang per stasiun pengamatan

Indeks keseragaman ikan karang ditemukan berkisar 0,86-0,93 (Tabel 7). Nilai keseragaman stasiun stasiun I yaitu 0,88 , stasiun II yakni 0,86 dan stasiun II sebesar 0,93. Berdasarkan kategori nilai, maka indeks keseragaman jenis menunjukan bahwa komunitas dalam keadaan stabil. Hal ini menunjukkan bahwa spesies yang ditemukan lebih merata pada setiap stasiunnya karena tidak terdapat spesies yang lebih dominan (Nasir et al, 2017). Krebs (1989) mengatakan bahwa kisaran nilai $0,75 \leq 1$ menggambarkan komunitas stabil. Pola sebaran dan dominansi ikan karang yang rendah pada setiap stasiun pengamatan, mempengaruhi kestabilan komunitas di suatu perairan. Penelitian Yunaldi et al (2011) melaporkan bahwa ditemukan kondisi komunitas tertekan hingga stabil di perairan Buleleng.

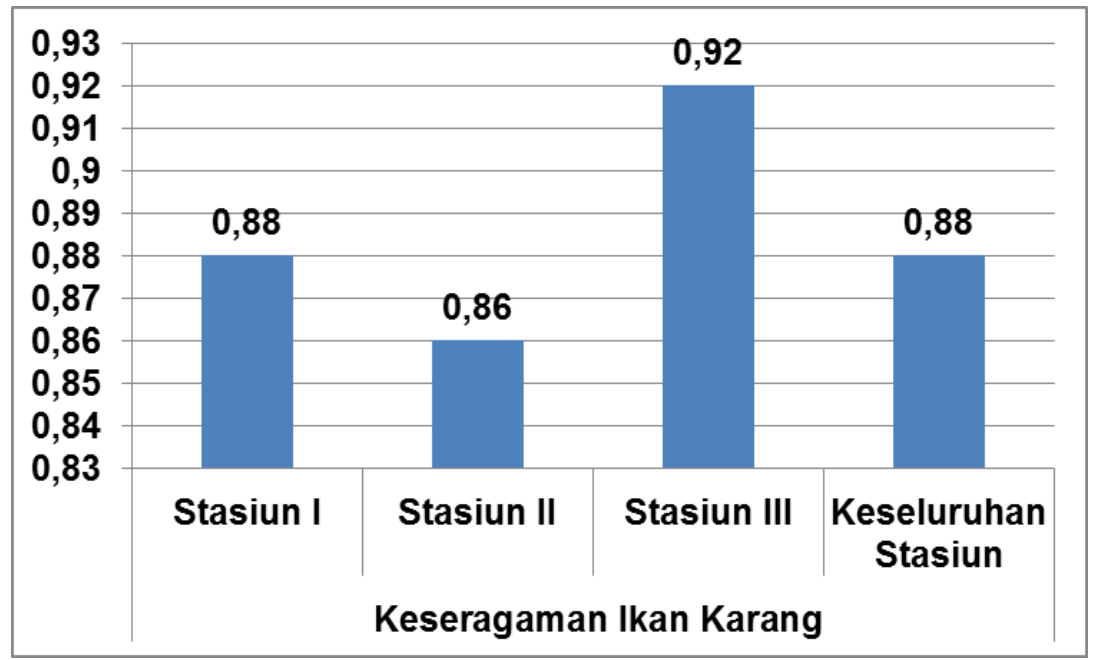

Gambar 7. Keseragaman ikan karang per stasiun pengamatan 
Selain itu kestabilan suatu komunitas ikan dipengaruhi dengan aspek keanekaragaman. Indeks keanekaragaman ikan karang yang tinggi, menunjukan bahwa komunitas dalam keadaan stabil. Odum (1993) menyatakan bahwa makin besar nilai keseragaman menunjukkan keragaman spesies yang tinggi. Kondisi terumbu karang yang baik memberikan peluang akan komunitas ikan karang untuk hadir dan berkembang didaerah ini. Hilangnya ekosistem terumbu karang akan memberikan pengaruh terhadap ketersediaan ikan karang di suatu perairan. Sistem ekologi yang terjadi mengakibatkan keterkaitan antara ikan karang dan terumbu karang. Faktor fisika perairan juga mempengaruhi keberadaan ikan karang disuatu perairan. Kondisi oseanografie seperti arus membawa material organik yang berlimpah untuk dijadikan sebagai makanan ikan karang. Selain itu suhu,salinitas dan $\mathrm{pH}$ perairan yang stabil memberikan peluang suatu perairan dijadikan sebagai habitat ikan.

\section{Kesimpulan}

Hasil pengamatan ikan karang di perairan pulau Maitara disimpulkan bahwa ikan karang yang ditemukan 6 famili, 16 genus dan 49 spesies yang dibagi ke dalam 2 kelompok yakni ikan indikator dan target. Kualitas perairan masih sangat mendukung keberadaan terumbu karang dan ikan karang, berdasarkan Kepmen LH No. 51 Tahun 2004. Kelimpahan dan Keanekaragaman kategori tinggi, dominansi rendah serta kesaragaman menunjukan komunitas stabil

\section{Daftar Pustaka}

Adrim M, Harahap SA dan Wibowo K. 2012. Struktur Komunitas Ikan Karang di Perairan Kendari. Ilmu Kelautan, 17 (3) 154-163

Akbar N, Haya N, Baksir A, Harahap Z A, Tahir I, Ramili Y, Kotta R.2017b. Struktur Komunitas dan Pemetaan Ekosistem Mangrove di Pesisir Pulau Maitara, Provinsi Maluku Utara, Indonesia. Jurnal Depik 6 (2) : 167-181

Allen, G.R. 2005. Coral Reef Fishes of Southwestern Halmahera, Indonesia. Report of Halmahera Survey, 2005.

Allen, G.R. 1999. Marine Fishes of South-East Asia. A Field Guide for Anglers and Diver. Periplus Edition, Hong Kong. 292 pp

Aryani, A. 2011. Studi Kelangsungan Hidup dan Pertumbuhan Karang Acropora formosa menggunakan Teknologi Biorock di Pulau Barrang Lompo Kota Makasar. Thesis. Manajemen Sumberdaya Perairan Jurusan Perikanan Universitas Hasannudin. Makassar.

Bakhtiar D, Djamali A, Arifin Z, Sarwono T. 2012. Struktur Komunitas Ikan Karang di Perairan Pulau Tikus Kota Bengkulu. Prosiding Seminar Nasional dan Rapat Tahunan Bidang Ilmu - Ilmu Pertanian BKS - PTN Wilayah Barat Tahun 2012. $4-17 \mathrm{Hal}$

Cinnawara H T, Mallawa A, Rani C, Idrus R.2015. Community Structure of Reef Fish in Eastern Luwu Water Territory. International Journal of scienctific \& Technology Research 4 (1) :213-215

Dahuri, R. 2003. Keanekaragaman Hayati Laut. Aset Pembangunan Berkelanjutan Indonesia, Jakarta : PT. Gramedia Pustaka Utama

Dhahiyat Y, Sinuhaji D dan Hamdani H. 2003. Struktur Komunitas Ikan Karang di Daerah Transplantasi Karang Pulau Pari, Kepulauan Seribu. Jurnal Iktiologi Indonesia, 3 (2) : 87-94 
English, S, C. Wilkinson and V. Baker. 1994. Survey Manual for Tropical Marine Resources. Australian Institute of Marine Science. Townsvile.

Krebs, C. J. 1989. Ecological Methodology. New York. NY Harper and Row Publishers Inc. $654 \mathrm{p}$

Lembaga Ilmu Pengetahuan Indonesia. 2015. Survei Basline Coremap CTI, Kondisi Terumbu Karang dan Ekosistem Terkait di Ternate, Tidore dan Sekitarnya, Maluku Utara. LIPI ; Pusat Penelitian Oseanografi, Jakarta. 76 Halaman.

Lembaga Ilmu Pengetahuan Indonesia. 2016. Monitoring Kesehatan Terumbu Karang dan Ekosistem Terkait Perairan Ternate dan Sekitarnya, Provinsi Maluku Utara. LIPI ; Pusat Penelitian Oseanografi, Jakarta. 66 Halaman.

Peristiwady, T. 2006. Ikan-Ikan Laut Ekonomis Penting di Indonesia. LIPI Press. Jakarta.

Terangi. 2004. Panduan Dasar Untuk Pengenalan Ikan Secara Visual Indonesia. Indonesian Coral Reef Foundation (TERANGI). Jakarta

Veron, J. 2000. Coral of the World. Australian Institute of Marine Science.

Marsaoli, M. 1998. Hubungan Persentase Penutupan Karang Hidup Dengan Densitas Beberapa Jenis Ikan karang Di Perairan Kepulauan Karimunjawa Jepara. Institut Pertanian Bogor. Tesis.

Mayunar. 1996. Jenis-Jenis Ikan Karang Ekonomk Penting Sebagai Komoditi Ekspor Dan Prospek Budidayanya. Oseana, 21 (3): 23 - 31

Najamuddin, Ishak S, Ahmad A. 2012. Keragaman ikan karang di perairan Pulau Makian Provinsi Maluku Utara. Jurnal Depik, 1(2): 114-120

Nasir M, Zuhal M dan Ulfah M. 2017. Struktur komunitas ikan karang di perairan Pulau Batee Kecamatan Peukan Bada Kabupaten Aceh Besar. Bioleuser, 1(2):76-85

Nybakken, J. W. 1992. Biologi Laut Suatu Pendekatan Ekologis (Terjemahan Muhammad Eidman, Koesoebiono, Dietriech G. B., Malikusworo Hutomo dan Sukristijono). Gramedia. Jakarta.

Nybakken, J.W. 1993. Marine Biology: An Ecological Approach. Third edition. Harper Collins College Publishers. New York.

Nybakken, J. W., 1997. Marine Biology. PT. Gramedia, Jakarta

Ratnawati P, Priliska H, Sukmaraharja. 211. Kondisi dan Potensi Komunitas Ikan Karang di Wilayah Kepulauan Kayoa, Kabupaten Halmahera Selatan Maluku Utara. Prosiding Seminar Nasional, 11-22 Hal

Setiawan F, Kusen J D, Kaligis J D F. 2013. Struktur Komunitas Ikan Karang di Perairan Terumbu Karang Taman Nasional Bunaken, Sulawesi Utara. Jurnal Perikanan dan Kelautan Tropis, Vol 9 (1) : 13 - 18.

Satria H dan Mujiyanto. 2011. Struktur Komunitas Ikan Karang Di Lokasi Terumbu Karang Buatan di Perairan Teluk Saleh Nusa Tenggara Barat. Prosiding Forum Nasional Pemacuan Sumberdaya Ikan III. 1-26 Hal

Suharsono. 1996. Jenis-Jenis Karang Yang Umum Djumpai Di Perairan Indonesia. Proyek Penelitian dan Pengembangan Daerah Pantai. Puslitbang - Oseanologi. LIPI. Jakarta.

Odum, E.P. 1993. Fundamentals of Ecology. W.B. Saunders Company, Philadelphia, London. Alih Bahasa oleh: Samingan T. dan B. Srigandono. Gajah Mada University Press. Yogyakarta.

Yunaldi, Arthana I and Astarini. 2011. Studi Perkembangan Struk Tur Komunitas Ikan Karang di Terumbu Buatan Berbentuk Hexadome Pada Berbagai Kondisi Perairan di Kabupaten Buleleng, Bali. Ecotropihic, 6 (2) : $107 \cdot 112$ 